\title{
The Cultural Roots of Contemporary Islamic Terrorism and Ways of Confronting It
}

\author{
Hani Ahmed Shboul ${ }^{1}$ \\ ${ }^{1}$ Al Balqa'a Applied University, Jordan \\ Correspondence: Hani Ahmed Shboul, Al Balqa'a Applied University, Jordan. E-mail: hani0789@bau.edu.jo \\ Received: March 27, 2016 \\ Accepted: April 8, 2017 \\ Online Published: May 10, 2017 \\ doi:10.5539/ach.v9n2p29 \\ URL: https://doi.org/10.5539/ach.v9n2p29
}

\begin{abstract}
This study aims at analysis and explanation of the phenomenon of the Islamic terrorism from a cultural perspective; i.e. a cultural reading of the religious violence phenomenon, and how the cultural systems would view the religion-induced use of violence at various levels. Generally, the unique nature of a culture sustains as well as revitalizes certain variants of extremism and terrorism.

In the present study, the hypothesis was that the prevalent sociopolitical culture dominating the thinking of the majority of Arab Muslims, which is originally inspired by the religious and historical repertoire, was one of the most effective mechanisms producing extremisms and terrorism. Hence, to stand up to terrorism most effectively, the overall thinking shall be revolutionized towards a civic culture drawing on which to establish the critical mindset based upon novel social values that are capable to interaction with the most recent breakthroughs of the contemporary civilization of the globe.

The researcher, as a consequence, recommends reproduction of the current Muslims' culture by employing the educational and media institutions to disseminate an open-minded civic culture that tolerates with others, and accepts multiculturalism and diversity. To that end, the researcher adopted the Content Analysis approach to analyze the content of the dominating culture and its relation to the production of terrorism and ways of confrontation.
\end{abstract}

Keywords: Culture, Terrorism, Reason, Transmitting, History, Islam

\section{Introduction}

The widely noted observation that the today's Arab communities live in a state of miserable "intellectual backwardness "; and the recent spread out of religion-driven terrorist and extremist acts are undeniable.

The reason is that the "culture" embraced by major part of the Arab communities, which defining their ways of thinking, belongs to the "Medieval Period" of the history, lagging behind the "intellectually" enlightened ages, and defies emancipation from that historical moment; while the use of critical mind and free thinking stigmatizes both the Arab culture and Islam as a religion (Alaiddin, 2016).

Generally, the culture dominating the thinking of most Arab Muslims that (forms their visions, life standards and political ideologies) is mostly a "traditional culture" originally emanated from fundamentalist Islam and an idealized Islamic history, which is most frequently reemphasized at home, school, college, mosque and other media channels. This traditional culture interacts with an extremist and politicized religious discourse, delivered by a group of mediators in the community, that conceptualize the difficult problems encountering the Islamic Arab communities, both internally and externally, relying on a historical and religion-driven explanation that finally form a catalyst environment precipitating religious extremism among young people, who suddenly, find themselves amid the vicious circle of terrorism (Ben Nabi, 2002).

Pedagogy and socialization that based on cultural haughtiness portrayed by bigot religious discourse derived from misrepresentation of Islam (deformed religious discourse, abusive fatwa, and parochial mindset) is another reason that if intermixed with poverty, illiteracy and ignorance, would inescapably create an environment that is averse to the culture of accepting diversity, tolerance, acceptance of others, and multiculturalism (Issa, n.d.).

To emphasize, the Arab culture is "traditional" that embarked at a specific historical moment, and successfully reacted to questions and problems arisen at that historical moment. Ironically, the time, the historical moment and 
the needs have all changed radically in the current age. It is necessary, therefore, to critically review the essential components of traditional culture, in order to be able again to give obvious answers to the questions and problems provoked in our recent age, instead of merely relying in religious fundamentals and historical philosophies that evolved in Middle Ages.

Ambushing behind a stronghold of history to cling its outdated heritage and philosophy-the key component of today's Muslim Arab's traditional culture-will produce only a stony Salafism and unacceptable religious extremism in the age of information, hegemony of globalization, and dissemination of the liberal thought. So doing will surely trigger terrorism acts both by extremist or Salafist groups, or even by countries which represent its selves as being founded on religion and historical bases.

Obviously, the extremist religious movements make use of the instinct religiosity, and exploit the idealized Islamic history for political purports; and by disguising its political discourse in a legitimate gown they set out to infidelize others or call them as heretics for one purpose that is to dominate the authority; because they deny democracy and disbelieve in the democratic thought or its philosophical bases (Issa, n.d.).

To summarize, most streams of extremism and terrorism are outsourced from the traditional culture, particularly the religious heritage, historical beliefs and thoughts constantly reproduced in the Arab communities that date back centuries ago. The message heralded by the terrorist and extremist groups strictly aligns with the culture dominating major part of the Arab communities, and not different from the pedagogical content being learned by students at schools, universities, and Faculties of Sharia in the Arab and Islamic countries (Gharaibeh, n.d.).

\section{Significance of the Study}

Hopefully, the results from the present study will have implications towards achieving the intended targets, most importantly to have a careful glance to cultural reform and constitute a human rights-oriented civic culture. This process includes reviewing and evaluation of the National and Civic Education curricula, especially at the college level in the Arab and Islamic countries, in terms of goals and content to keep track with the general policy of the Arab countries to downsize the religious bigot and intellectual terrorism by encouraging a sociopolitical culture to immunize the Arab and Islamic communities against religious extremism and protect their sons from being allured into the terrorism groups.

\section{The Intellectual Mentality of Arab Culture}

Essentially, the Islamic Arab culture evolved based on sacred religious texts of the Koran and the traditions of the Prophet (Hadith and Sunna), and related classical explanations that had developed over the Medieval Ages. There is no "presence" of human reason in the constitution of the Muslim Arab culture, in that no one may give an explanation of the religious text using his opinion; instead he is required to keep up with text in strict compliance with opinion and explanation of old scholars; meaning that the Classical Mind has the first word and predominating today's current deeply-rooted culture that represents the culture embraced by majority of the Muslim Arabs (Al-Jaberi, 2003; Masoud, 2003).

The religious text as explained by oldest scholars, and the idealized Islamic history is induced by major religious institutions, Muslim scholars and preachers who with dexterity use many sites on the Web, and are most often invited by many satellite channels to appear live on air only to humiliate human mind, and underestimate its function of thinking, comprehension, and awareness. They keep promulgating their outworn anecdote of human all-knowing incapability assuming that the religious text, with its most classical explanations, takes supremacy on mind.

These entire institutions heralding that the correct worship of Allah is to obey His order whether it was making any sense or not; and view the proponents of the rational approach who introduce mind a step ahead the Koran and Sunna as a classically new invention; the disruption and disorder of the world, they argue, originates from accepting the human's opinion first to the God's revelation; and that Allah created human brain with limited powers, that it is unable to perceive much of the things around it; and Allah knows the interest of people much better than they are (Sheikh, n.d.). All of this negatively affects today's Arab thought and culture and affects the attempts of modernization as well.

In the culture of Arabs and Muslims, the concept of "Islamic Sharia" means the duty of strict compliance with the legislations date back to the Middle Ages: for instance imposing upon women wearing the hijab, cutting off hands of a robber, cutting heads, stone-throwing to death, these penalties are viewed as "the sacred sharia of Allah", and should never be derailed. As for "Jihad", the goals include creation of an Islamic State that apply Islamic sharia ruling. 
On the other hand, the seminal sources on which the Islamic Sharia had been entrenched include first the Quranic text, and then the inherited excerpts of the Prophetic Sunna (Hadith) and schools of the Prophet's Companions and Followers. This point again reminds us with the deeply-rooted 'conception' in the mind of most Muslims no matter to what sect they belong i.e. that the Islamic Sharia is complete, integrated and inclusive to all aspects of life since its origination in the $7^{\text {th }}$ Century AD in the Arab Peninsula; and that it is transnationally valid for each time and space (Yousef, n.d.).

The worst is the believe that anyone who dissents from that 'conception' is described by the Muslim Fuqaha (religious jurists) as being infidel and converted from Islam. This attitude is evident in the following Islamic Fatwa that states: "belief in the comprehensiveness and validity of Islam for each age and place, and responsiveness to various religious and worldly requirements of humanity is a religious duty; and whoever believed that Islam is valid for one age but not the other, and for one class but not the other; or else that another ideology is valid for or gratifying people's interest more than it is; shall be an infidel... and this is a self-evident religious fact. Consequently, whoever denies comprehensiveness and validity of Islam as described above shall be an infidel converted from Islam" (Islam Web-Fatwa Center, n.d.).

A glance should be made that the conservative fundamentalist thought that embraces the old interpretation of Islam (transmitted), excepts and denies human reason and rationalism was historically developed in works of a number of more prominent scholars like Imam AL Shafei (Died: 820 AD, Fustat, Egypt), Imam Ahmad bin Hanbal (Died: 855 AD, Baghdad, Iraq), Imam Malik bin Anas (Died: 795 AD, Medina, Saudi Arabia), Imam Abu Hanifa Al Nu'man (Died: 767 AD, Baghdad, Iraq), and IbnTaymiyyah (Died: 1328 Ad, Damascus, Syria). The sort of thought theorized by such Imams, and the sharia they coined are still dominating the cultural thought of the Arab communities (Ministry of Wakf \& Islamic Affairs-State of Kuwait, 2015).

Traditionally, Muslims have been envisaging the Islamic Sharia as being a series of "do's and don'ts" that rarely leave, but a narrow space, for choice or contemplation. So, obeying Allah in the heaven has turned to be a sort of obedience to human icons on earth whether a ruler, religious scholar, or Imam, and ultimately, the Arab mind have become totally paralyzed; as no questions allowed to be asked out of the formal framework vis-à-vis ready-made religious conclusions that were released by the Ulema, Imams and masters, with a determinist result i.e. decay of the sense of criticism, which is the momentum for any real development of communities.

The Arab Muslims of today are not only convinced that what holds valid for a specific age will necessarily holds valid for all ages, but also give a sacred hallo to the formal history, and classic ancestors in the collective mind of Arabs. This conviction per se plays a key role in the rigidity and stagnation of the Arab Muslim mind. This situation made the Arab culture aversive to the time, development, and inability to apprehend the dialectic movement of time (Shareef, 2013).

No doubt that the feelings of proud with a noble past have played a part in cohesion and solidarity of the Arab communities, and elevate the morality among Arab peoples. However, if national proud was built on wrong bases then the harm would be far-reaching, that it is important to reconsider self-criticism, revisit the shortcomings and flaws in order to tackle them with brave and find solutions.

The analysis reveals that Arab 'Traditional Reasoning' stands in sharp discordance with the central element of modern civilization that is human Reason and Rationalism; the traditional mind, as a result, views Reason and Rationalism as being the antithesis of religion; and this explains why most reformers and radicals have been victimized as being targets of intellectual terrorism and were notoriously defamed as being heretics with accusations of criticism of the sharia and sarcasm of sanctuaries (Shareef, 2013).

In reality, the entire civilizations of the old world have been relying on mythological explanations of phenomena of life and the universe. Despite the other cultures could detach itself from the world of mythology and fantasy to hook up with a new reality of Reason World, the Muslim Arab intellect remained as always entrenched on the oldest hocus-pocus fancies, without crystallizing stronghold against fanciful witchery.

The problem with the Arab culture is the strongly held dualism of opposed substances, for instance: angle/Satan, believer/disbeliever, permissible/impermissible, and dwelling of Islam/Dwelling of infidel.This duality, in fact, invalidates the role of human reason, and makes futile a constellation of values, ideals rules and statutes that have been crystallized through experience over the human history.

At another level, taking Imam-based fatwa as a reference to identify what is permissible or not means one to neutralize Reason, and resort instead to commentators of the religious texts by surrendering to Sharia scholars to differentiate between what is right or wrong; or to identify what should or shouldn't be done in the various life situations. The (halal/haram) permissible/impermissible duality stands as a hurdle precluding receptiveness of 
democracy by the Arabs. Depending on such dual reasoning, there is no middle ground, contrary to democratic thinking that mainly is built on accordance between different views, settlement, and stands in the middle distance between two extremes without seeing one as representing permissible and the other impermissible things (Shareef, 2013).

The Islamic reading of history that is rooted in the Arab cultures starts out from a seminal perception of human, in that the human history symbolize the embodiment of the divine will through human acts as preordained by God. The outlook to other people may not principally divide nations based on their position on the scientific or economic advancement scale, for instance developed/developing; or by military or political power into strong/weak nations, instead the Islamic explanation divides people into two main camps: believers and disbelievers (Mohammad, 2006); and the human history is not but a struggle between the right and wrong, goodness and badness, between partisans of God opposite to the Satan (Mohammad, 2006). The religious narrative not only relies on classical texts and knowledge, but also colors the whole life with its spirit, in a way that penetrates every aspect of life. The Islamic culture is one-sided fascism, disguised in saintly appearance, it's deeply- rooted approach of 'transmitting the old interpretation of religious text' is to immunize itself with powerful effect in the community (Sami, 2015).

The flesh and bone of this heritage immunizes every paradox and fallacy from an insightful intellectual argument, which opens the door to rigidity, backwardness and acceptance of the paradoxes as being valid universals; so, one needs to take as a given the entire heritage, with absolute absence of mind. This intellectual position generalizes to all aspects of life, in that not only the religious text is that immunized, but the whole prevalent Arab Islamic culture.

This discussion demonstrates how the Arab culture turned to a defensive culture, celebrating a dignified-past, self-importance, and justification of the status quo, and negating others who dissimilar. This attitude created a deep knowledge gap between Arabs and the West in the cultural, technology and scientific fields.

To summarize, the Arab culture is patriarchal, past-oriented, conservative, and traditional in nature that continued clinging the traditional intellectual and societal structures without experiencing any serious attempt for renovation or renewal at the level of cultural, social, religious or political discourse. In fact, the powers of both the Fuqha and Imams had the prominent inhibiting role against any cultural trend towards more tilt to a centralized role of Reason (Ahmad, 2011). In consequence, the classical Arab culture still strong and effective that it can resist any trial of modernization considering its role in coining the self, and fleshing out the collective "we" to the level where the historical moment has become the mentally idealist element of the Arab self.

A note should be made here that such determinist mindset- that eliminates any role of rational mind, deactivates the human will, and cancels human acts - has been the winner over history, and today still actively dominating the intellectual approaches of the Arab Muslim communities, and on the other hand still exploited, invested and manipulated politically (Ahmad, 2011).

At this point, we can argue that the problematic relationship between "Reasoning" and "Transmission" is very old, and the intellectual desertion of the enlightened heritage on the Arab scene dates back deep in history over long centuries. The result was hegemony of an irrational salafist culture that yielded a self-producing cultural environment restricting or even inhibiting any attempt of intellectual renovation; and this problem still dominantly visible in the Arab culture (Ahmad, 2011).

The classical interpretation of the religious text produced a culture of negation, infidalism and cancelation of others in way, finally separating Arabs from the rest of the world, and also damaging human 'Reason' and 'Rationalism' under the gown of religious text. Similarly, the fears of being accused as infidel have historically resulted in poor thinking and innovation (Ahmad, 2011).

Arab Muslims still live in fancies of supremacy, in the spiritual and humanitarian, depending on their historical civilization. The argument here is call for restructuring the Arab cultural thinking, by setting as pivotal the reason and critical thinking instead of transmitted religious text, and this attempt, as we believe, would serve as a positive contribution to stimulate the contemporary Arab mind towards modernization.

\section{Resistance of Modernization}

A glance to most prominent features of the Arab thought since the $20^{\text {th }}$ century reveals the challenge for most Arab countries was not only an imperial but also a cultural challenge that the West has become a source of cultural threats as represented by the cultural invasion with aims of wiping out Arab Islamic ethos, and instilling essentially Western ideas in economics, sociology and culture. 
The recent globalization with its attempts to create a universal system of values has been represented as "an idealized danger" threatening the Islamic peculiarity as defined by members of the extremist Islamic groups.Generally, the fundamentalists deny all varieties of the Western modernization, and criticize the Western civilization as being the one, not any other else, that excreted imperialism that ended up the Islamic Caliphate, and occupied many Arab and Islamic countries during the imperialism era.

One might agree with the Islamist criticism against the Western imperialism; however we decline their unreserved generalization that the Western culture altogether hostile to fine values of humanity related to freedom, justice, and equality, and the Islam and the Islamic communities too.

However, one can say that the absolute refusal of the Western culture is not the worst; it is indeed the allegation that the Arab Muslim countries are plight with inferiority because of the embracement of the Western modernization, including application of the legal positivist system in replacement of the Islamic sharia law (Al-Syed, 1991).

The bigot against the West had a significant role in frustrating the cultural modernization scheme, possibly as a result of the parochial reaction to the modernization shock among the traditional classes, which crystallized in the establishment of the Muslim Brotherhood Movement in Egypt 1928 that was a stubborn opponent to an unobstructed interaction with the Western civilization and its moral and materialistic components (Al-Syed, 1991).

During the second half of the last century, the Islamist fundamentalist groups have proliferated with little or no attention to modernization and rational enlightenment. Instead they were more focused on ideological conflict and political mobilization. This is so due to the traditional religious discourse with its vision opponent to science and modern technology. The traditional religious discourse address scientific facts (mainly social sciences) with doubts and equivocal, believes that the scientific facts are relative, variable, limited in scope, and not fixed vis-a-vis the religious facts that are absolute, not governed by time or space, undoubted, unreviewable, and not prone to criticism (Mohammad, 2000).

Furthermore, the Islamic discourse is abundant with doubts about the modern social structure basically the democracy that they describe as a sort of infidelity, because democracy considers people the source of authority, which, in their view, contradicts with religion since God is the only source of authority and legislations. Taking this in mind, the civil society, human rights and advocacy organizations are described as being secular, worldly, anti-spirit, equalizes between Muslim and non-Muslim, and replaces sovereignty of God by that of the nation (Mohammad, 2000).

Early of the 1980s the extremist Islamist current started to grow fast with increased expansion in both size and influence on the folk culture. The development had accompanied by retreat of the developmental role of the Arab Muslim countries principally on the cultural modernization level.

In reality, the problem with the Islamist current is that it has diverted the phase supposedly of renaissance, enlightenment, and modernity into a phase of self-defense against the culture of the West without differentiating between what is good or bad. The reason for the failure to transfer the scientific and technological modernity from the West, Arkon argues, is that the material modernity was imported isolated from its essential requirements i.e. the cultural modernity (Mohammad, n.d.).

They did not realize that the intellectual modernity produced the material modernity, and there is a dialectical relationship between them that prevent acceptance one without the other. The transfer of the scientific thinking and the epistemological methods is no less important than importing modern technology.

Contrary to other nations, including less developed, the Muslim people are still clasp with the governance of the Medieval ages: governance of the religious reason; they did not make the necessary shift to governance of the modern ages i.e. governance of the human reason, where the reason takes supremacy in every field of politics, science, economics, literature, arts and even the reformed rationalized religion. Every step towards transition into the governance of the human reason and rationality instigates panic in the Islamic rightists designating this development as "falling in the $20^{\text {th }}$ Century Ignorance" (Mohammad, n.d.).The vast majority of both the elites and the common people still cling to the concept of Association "walaa"/Disassociation "baraa" which strongly founded in the Holy Quran: "O you who have believed, do not take the Jews and the Christians as allies. They are [in fact] allies of one another. And whoever is an ally to them among you - then indeed, he is [one] of them. Indeed, Allah guides not the wrongdoing people" (Quran, n.d.).

This Quranic verse indicates that the association "taking allies" shall only be Muslim-to-Muslim, and decline or dissociate from Jews and Christians and the disbelievers in general .. refuse them as persons, their ideologies, institutions, disciplines, values, and their thinking patterns as well. The attitude of Association/Disassociation 
(walaa/baraa), as argued Ayman Al-Dhwaheri in his work "Nights under the Prophet's Flag", Al-Qaeda's Bible in its globalized jehad, and described association with non-Muslims as being a reason for casting them out of the Mellet "religious community". This sort of thinking formed a mental restriction for Muslims to integrate with civilizations principally made by non-Muslims, and formed a conscious or unconscious deterrent for Muslims to reintegrate in their new communities in countries to which they migrated, without which they possibly could have no future! (Quran, n.d. Al-Afif Al-Akhdar).

Ultimately, the Arab mind-set remains the main obstacle precluding modernization, and the questions of 'Reason', Freedom and Enlightenment still unasked due to prevalence of religious tyranny, and irrational behaviors that served as a fertile soil for growing extremism and terrorism.

\section{Terrorist Intellect and Relation with the Traditional Culture}

The phenomenon of Islamic terrorism is inseparable from the traditional discourse that still penetrates all parts of the Arab community. The primary features of the Islamic traditional discourse is characterized by clasping with chosen past, escaping from tackling the realities, denying changes taking place globally, irresponsibly blaming enemies for any fault or failure, and typically explains history with conspiracy theory, and the tendency towards fabricating fanciful worlds to which they call for application irrespective how practical such worlds (Quran, n.d. Al-Afif Al-Akhdar).

Notably, the times of the Islamic Caliphate, and primarily the early period of the first four caliphs, are idealized by most Muslims as being the golden age of Islam to which most Muslims aspire to live again its moral system and under its guidance (Quran, n.d. Al-Afif Al-Akhdar).

However, that deep history was not in any day that floral picture as typically wrongly idealized by the Muslim and Arab peoples. The review of the Islamic history resources that documented the event of those times reveal a dissimilar picture that even contradicts what usually installed in minds.

This is how the yearning to a legendary idealized history, on which grown generations of the Arabs and Muslims, turn into a resort or an escape out of the state of helplessness they live today; and the allegory with other world peoples reveals a vast gap between the advanced nations and Islamic nations that live on fancies of the past without producing anything, instead they are consumers of what others produce.

This partially explains why some of Muslims join the terrorist groups and are willing to die in its path. They imagine that the unfavorable economic, social and political situations in most Arab and Islamic countries, including the poverty, tyranny, and corruption are consequences of abandonment of Islam and relinquish application of the Islamic sharia law, that they are willing to sacrifice themselves until Islam becomes lived again, and to revive the noble history lost by the Islamic community until return back again, as they believe.

This case in specific is invested by the Wahhabite movements that imagine the idealized history as being the theriac to cure all ailments of the time and assist resume the path with guidance form of the ancestors (Quran, n.d.). The believe that doing so requires first removing the infidel regimes of Islamic countries whose leaders are apostates.. defectors from Islam and allies of the West. The legal positivist system shall terminate because it is "infidelity" and apply the Islamic sharia law instead.

The mental disposition of the Arab cultures revolves around the idea that the whole world conspires against the Islamic World, and every place outside Islamic World is seen as a dwelling of infidels (dar-al kufor), that should be invaded and battled.. this misperception arises partially from incorrect explanation of the Quranic verse: "And never will the Jews or the Christians approve of you until you follow their religion" (Quran Kareem, n.d.).

A Muslim always interprets events from the conspiracy perspective, as conspiracy by Jews and Christians against Islam. The extremist and terrorist Islamic groups emphasize on such myths in their publications and media.. and talked on by common people... the repetition of the same talk over long years instilled its deep in the traditional culture of most Muslims and has been taken-for-granted. This is why we see large empathy with the armed terrorist groups among some common people in the different Islamic countries when they attack targets in the Western countries; they in fact consider these groups the defender against the enemies and the protector of Islam.

Essentially, that relationship with the world has been established. Usually, the extremists and terrorist do not use civil or military words in order to differentiate between the targets they choose to practice violence. Instead they divided the Earth into two worlds: Dwelling of Islam (Dar-el Islam) and Dwelling of Infidel (Dar-el Kufor). Of course, the Dwelling of Infidel conspires against Islam in order to exploit their wealth and impose their hegemony, and also give hand to the oppressive regimes defected from Islam because they refrain from applying the Sharia law. As result, they are preoccupied with ideations that all the surrounding worlds, notions and humans are conspiring against Islam (Ali, 1996). 
The important concept of "worldview", which is essential in the cultural analysis, implies how a culture views the universe, community and human; can help understand the key reasons behind terrorism. The culture of the terrorist groups has its own worldview by which explain the universe, community and human using religious and historical explanations. The concept of "Governorship" that stresses on that governorship shall be to God not humans; further the attitude of infidelize Arab and Muslim communities, ascribing to them deviation from the final ends of the religion, in addition to deep hatred to foreigners on ground that they are disbelievers and atheists; they launch a crusader war against the Dwelling of Islam, which justify declare Jihad against them, all of which are the key features of the parochial traditional worldview, which is the key prerequisite for synthesis of the "Terrorist Reason" (Al-Sayed, 2014).

The traditional reason, therefore, is the prerequisite for terrorist reason. When an attempt is made to explore the components of the terrorist reason, we might discover an abundance of convictions arise from the traditional culture, most importantly that Islam is self-sufficient, perfect, and comprehensive, and also valid for all space and time. Behind such eloquence one can hear an elaboration about the flourish times of the Islamic civilization, and rehearsed preach about enemies who by the Islamic sharia should be battled (Al-Sayed, 2014).

To promote their bigot ideologies, infidelize others (basically intellectual antagonists), the extremists employ the "fatwa", which widely accepted by the common people with traditional culture. For instance, the "fatwa" formerly released by Mohammad Omara (an extremist Islamic Theorist) that "Secular Muslims who do not believe that Islam is 'state and religion' are infidels" (Al-Sayed, 2014).

The argument that the traditional reason is necessarily a precursor of the terrorist mind-set that instigates one to commit terrorist acts with the justification that they are a sort of "Jehad in path of Allah", then the essential components of the traditional reason cannot be understood in light of other than "fundamentalism", i.e. the ideological rigidity and intellectual orthodoxy" (Ali, 2003).

In effect, the thinking of the fundamentalists takes place outside the modernization problems, since thinking in development resides within space and time frames; however, the fundamentalist thinking is out of space and time; it is contemplation in the sacred text out of time. The fundamentalists deny modernization because it is alienation in two meanings: alienation with Islam in that one becoming impious and secondly alienation in the meaning that modernization is modeling the West (Ali, 2003).

For the extremist fundamentalist thought, Islam denies any dialog between civilizations; Islam according to this fundamentalist thinking should prevail not only by missionary activities, but also by Jehad, meaning enforcement of the idea of religiosity by violent and terrorist means (Abdallah, 1995). Hence, the organic connection between the fundamentalist traditional reason and the terrorist reason become clear.

\section{Cultural Policy to Confront Terrorism}

The main question asked here is how to face terrorism? The classical answer is by using security means, which, in our opinion, is unproductive; because security is not adequate to confront terrorism. The other answer that the current study adopts is the cultural policy approach that is based on profound cultural analysis of the phenomena of terrorism and extremism.

The security approach, that is necessary but inadequate, include a set of confrontation means, like the policy of destroying the extremist networks, confront terrorism via law enforcement system and police, stirring divisions among the various terrorist groups by applying the emblem "Divide and Rule", single out most extremist members, tolerate with the moderate member until their discourse prevail the society with concentration on moderation. The most notable means of confrontation is the decisive violent confrontation with the extremist members to root them out of the society.

Following we will discuss the cultural policy approach to tack with terrorism.

First, we will attempt to conceptualize the phenomenon of terrorism, which is in reality "a conflict between the community and terrorist self" that seeks to radically change the world even by killing others through bombing, or self-murdering as when a bomber explodes his self, believing that doing so is a triumph for the extremist ideology he embraces.

In this context arises a major question: How to explain the phenomenon of terrorism and identify the terrain of the intricate and complex factors leading to terrorism in varied communities in terms of cultural and social histories and varied from the economic backgrounds?

The "social mobility" recognizes that the public oppression, relative deprivation, political suppression, and social tensions not adequate to explain why some violent motifs appear to surface (Al-Syed, 1991). 
In this spotlight, one cannot attribute terrorism causes to poverty or political suppression as many terrorists belong to wealthy classes. Furthermore, not every Arab citizen expose to political suppression might easily slip-up into terrorism. The explanation would be that the terrorist groups practice brainwashing of specifically young people, and charge them with conservative traditional vision pretexting maintenance of the religious values that are at risk of extinguish as a result of the modernity process taking place in the community or else instigating those youngsters against foreign military occupation or the foreign interests in general (Al-Syed, n.d.).

To eradicate terrorism, that has multiple causes, we need a comprehensive humanistic initiative that place human central to cultural development process. Peace cannot be accomplished only through economic and political development. To conquer terrorism, we need to replace traditional culture with a civic culture that gives supremacy to critical thinking, maximize the human capital, enhance intellectual and moral solidarity, hatching the values of plurality and cultural and religious diversity, and establish the civilian state that value 'citizenship'. To really understand terrorism we in need for working on cultural vision and civilization scheme for the reawakening of the Arab World (Al-Syed, 1991).

This subject was the central issue approached by the Young Researchers Conferences organized by the Arab Research Center in collaboration with the Egyptian Youth Ministry in December 2014 under title (The Intellectual and Cultural Confrontation with the Phenomena of Terrorism and Extremism) on which valuable scientific contributions were presented and fruitful discussions were deliberated that led to a number of important recommendations deserve to be present here in order to see how young people visualize this problem, especially given that most partisans of the terrorist groups are basically young people.

The most important recommendation is the suggestion that the confrontation strategy with the terrorist groups should be multifaceted combining both security and cultural means in an integrated plan. The psychological means that the authorities can employ with the terrorist groups shall focus first on the multiple manifestations of their ideology, which is based on the adoption of extremist notions that exaggerate one's self and see other with inferiority.

The recommendations stressed also on the cultural policies that call for reshape the Arab Reason, which is traditionally coined by impaired educational programs that were keenly interested in producing a "copycat" rather than a critical mind that puts a big question mark on everything in the life" (Al-Syed, 2014).

From this point, the contemporary Arab communities shall bear the responsibility of nurturing the critical mind that places mind rather than the religious text as the criterion of judgment on things, this is possible if we could adopt the philosophical skepticism approach to question any taken-for-granted knowledge even the metaphysical beliefs.

This tendency shall have reflections on the cultural policy in general, with the focus on radical change of the educational system that is based on rote rather than analysis, and to rationalize the media system in order to become leverage for creative thinking, and finally to reshape the socialization patterns to support development and creative dialogue.

A closer look to the current Arab knowledge scenery reveals that the Arabs failed to accomplish the intellectual modernity similar to Europe that adopted Reason as the final judgment on things.

Contrary, the Arab culture continues to be dominated by religious texts, and penetrated by the rigid imprecations. This rigidity derailed the Arab culture towards a more orthodox religious thought that hampered the social and political mobility, and assisted spread out of extremist thinking that finally ended up to terrorism (Hakeem, n.d.).

In reality, a wider look at the development process in the Arab countries since 1950s to date reveals that the concentration was on the economic aspects, but the culture remained untouched. In fact, no society can advance no matter how large its economic achievements, without a parallel advancement on the cultural aspects, and being emancipated from the cultural blockade that prevents embarking intellectual initiation by individuals and groups, as well as political and social organizations (Nabeel, 2009).

No doubt that the significant approach to an effective cultural policy is to learn about the youth culture using scientifically reliable approaches in order to see how they visualize the world around them, basically through investigating the social media that are most frequently used by young people and have become platforms of sharing notions and values whether they are true or false.

In a word, to confront terrorism effectively we need a "cultural revolution" that generates a civilian thought and critical reasoning supported by active educational policies that create viable cultural values and able to interact with the advancement of the contemporary world. 


\section{Conclusion}

This article attempts to make it clear that the cultural reform including upgrading the way of thinking, and frame of mind is an essential means of combating terrorism, and instigating the different actors in community to ensure their support in combating terrorism and dry out its sources.

The phobia from the cultural reform is deemed as an indirect support of such terrorist groups, as they permanently and primarily benefit from the commonly prevailing cultures to justify their clashing discourse.

To emphasize, the cultural reform including renovation of the epistemological conceptualizations, and revisit the nature of priorities is altogether a means of anti-terrorism strategies, and to root out cultural and social causes that perpetuate terrorism. Surely, the cultural rigidity, intellectual looseness, and long reside on decayed cultural traditions sustain the situations that directly contribute and promote the terrorist discourse, its reasons and propositions.

In conclusion, we argue that the cultural reform that contributes to changing the social climate and the mind-set of the community starts by developing a secular civilian culture that separate religion from intervention in the affairs of the state, a culture that recognizes the principle of "citizenship" irrespective of religion, sect, ethnicity, race or political orientation, a culture that protects freedom.. there is no penalty for atheism.. unrestricted conversion of religion, with no reservation against any religious or intellectual faiths. With the single source of legislation being the parliament and legislators are the parliament members.

\section{References}

Abdallah, A. (1995). The Contemporary Arab Ideology (p. 51, p. 101). Arab Cultural Center.

Ahmad, M. S. (2011). Reason \& Religion, from aReformative to Secular Discourse (p. 178). Vision for Publishing and Distributing).

Alaiddin, A.-A. (2016). Vis-à-vis Backwardness: Towards a Comprehensive Arab Cognitive Structure. (E-Kutub. 2016, pp. 37-38).

Al-Hasan, B. T. (2016). Enhance the Dialogue, Solidarity and Peace in Face of Extremism. Al Ghad Al Ordony. Retrieved from http://www.alghad.com/articles/912431

Ali, O. (1996). Cultural Versus Political Power. Arab Unity Studies Center.

Ali, O. (2003). Dialog of Cultures: Obstacles and Horizons.

Al-Jaberi, M. A. (2003). Composition of the Arab Mind, Arab Unity Studies Center, Beirut, 2006, P138.

Al-Sayed, Y. (2014). Crisis of the Traditional Mind (1), "Al-Hayat". Arabic daily newspaper. Retrieved from http://www.alhayat.com/Opinion/Writers/4893198

Al-Sayed, Y. (n.d.). Crises of the Traditional Mind, (1), "Al-Hayat".

Al-Syed, Y. (1991). National Awareness under Siege: The Crisis of the Arab Political Culture (p. 102). Strategic \& Political Studies Center, Cairo.

Al-Syed, Y. (1991). National Awareness under Siege: The Crisis of the Arab Political Culture (pp. 125-126). Strategic \& Political Studies Center, Cairo.

Ben Nabi, M. (2002). Problem of Thoughts in the Islamic World (Dar El-Fekr, Damascus 2002, P77).

Gharaibeh, I. (n.d.). Religious Extremism is not but a Miniature of Longstanding Historical Religious Case. Retrieved from http://www.abouna.org/all-authors

Hakeem, M. (n.d.). Cultural Self Determination Protects from Extremism and Terrorism. Al-Arab, 10406, 13. Retrieved from http://www.alarab.co.uk/article

Islam Web-Fatwa Center. (n.d.). Fatwa No. 9263. Retrieved from http://fatwa.islamweb.net/

Issa, H. (n.d.). Extremism Preoccupies the Arab World. Retrieved from http://wbpalestine.com/

Masoud, D. (2003). Freedom \& Innovation in the Modern Arab Thought, Journal of Culture, 5, 19-21.

Ministry of Wakf \& Islamic Affairs-State of Kuwait. (2015). The Four Fiqh Schools, Author: Scientific Research. Retrieved from https://d1.islamhouse.com

Mohammad, A. (1998). Issues on Stoicism of the Religious Reason. Beirut.

Mohammad, A. (n.d.). Issues on Criticism of the Religious Reason (p. 263). 
Mohammad, A.-B. (n.d.). Interview with: Al-Afif Al-Akhdar on the occasion of his new book: "From Mohammad of Believe to Mohammad of History (in press). Retrieved from http://www.ahewar.org/debat/show.art.asp?aid=362003

Mohammad, M. (1991). History of the Islamic Sects (p105). Dar Al-Manar-Cairo.

Mohammad, O. (2011). The Islamic Sharia and Western Secularism. Dar Al-Shorouq, Cairo.

Mohammad, Q. (2006). On the Islamic Explanation of History (pp. 87-90). Dar A Shorouq, Egypt.

Mohammad, S. (2000). The Regions Discourse Resisting Science \& Technology. Al-Noor Journal, 173, 11-13.

Nabeel, A. (2009). The Arab Reason \& Knowledge Community (p. 88). Kuwait, Knowledge's World, December, 2009.

Quran Kareem. (n.d.). Al-Baqara (2:120).

Quran, K. (n.d.). Al-Maidah, 5, 51.

Sami, L. (2015). Culture of Pre-Mind Transmission and Route to Backwardness. Civilized Dialogue, 4682. Retrieved from http://www.ahewar.org/debat/show.art.asp?aid=449174

Shareef, A. S. (2013). Why Run Backward, While Other Run Ahead? Dar El-Ein Publishing House.

Sheikh, M. H. (n.d.). Renowned Preacher in the Arab World, a lecture on the Mind versus Excerpts. Retrieved from https://www.youtube.com/watch XgqZEKBA18E

Subhi, A. M. (2008). The roots of terrorism in Wahhabism (p. 138). Dar Al Mezan.

Suleiman, A.-A. (n.d.). Democracy and Attitudes of the Islamic Law towards It. Retrieved from http://www.almoslim.net/node/8998

The Conference was held in Cairo-Egypt, Saturday and Sunday 13-14 December, 2014. Al-Syed, Y. (2014). National Awareness under Siege (pp. 128-130). Arab Research Center. Retrieved from http://acrseg.org/39211

The Moroccan Researcher "Ali Omlail" in his research paper on the "Dialog of Cultures: Obstacles and Horizons" has prominently demonstrated the passive meanings of fundamentalism (Published in the collective works of the seminar: Dialog of Cultures: Is it Possible? Held in Rabat, January 2003.

Yousef, A. Q. (n.d.). Validity of the Sharia for Each Time \& Place. Retrieved from http://www.aljazeera.net/ programs/religionandlife/2004/6/3/

\section{Copyrights}

Copyright for this article is retained by the author(s), with first publication rights granted to the journal.

This is an open-access article distributed under the terms and conditions of the Creative Commons Attribution license (http://creativecommons.org/licenses/by/4.0/). 